University of Montana

ScholarWorks at University of Montana

8-1996

\title{
Abiotic Stress and the Relative Importance of Interference and Facilitation in Montane Bunchgrass Communities in Western Montana
}

\author{
John T. Greenlee
}

Ragan M. Callaway

University of Montana - Missoula, Ray.Callaway@mso.umt.edu

Follow this and additional works at: https://scholarworks.umt.edu/biosci_pubs

Part of the Biology Commons

Let us know how access to this document benefits you.

\section{Recommended Citation}

Greenlee, John T. and Callaway, Ragan M., "Abiotic Stress and the Relative Importance of Interference and Facilitation in Montane Bunchgrass Communities in Western Montana" (1996). Biological Sciences

Faculty Publications. 297.

https://scholarworks.umt.edu/biosci_pubs/297

This Article is brought to you for free and open access by the Biological Sciences at ScholarWorks at University of Montana. It has been accepted for inclusion in Biological Sciences Faculty Publications by an authorized administrator of ScholarWorks at University of Montana. For more information, please contact scholarworks@mso.umt.edu. 


\section{ABIOTIC STRESS AND THE RELATIVE IMPORTANCE OF INTERFERENCE AND FACILITATION IN MONTANE BUNCHGRASS COMMUNITIES IN WESTERN MONTANA}

Early ecologists emphasized the role of positive interactions in plant communities occurring in habitats characterized by intense abiotic stress (Clements et al. 1926; Allee et al. 1949). Until recently, however, positive interactions have been largely overlooked as important factors in community structure. In the last decade, renewed interest in facilitation has resulted in a number of studies that document the importance of this interaction in communities. Positive interactions have been described for sessile animals in intertidal zones (Witman 1985; Lively and Raimondi 1987) and for plants in a variety of environments such as deserts (e.g., McAuliffe 1988; Franco and Nobel 1989), salt marshes (Bertness 1991; Bertness and Shumway 1993; Callaway 1994), California oak woodlands (Callaway et al. 1991; Callaway 1992), and Great Lakes sand dunes (Kellman and Kading 1992; see review in Callaway 1995). Plants acting as facilitators may lower the soil surface temperature (Franco and Nobel 1989; Evans and Cabin 1995), decrease evaporation and hence soil salinity beneath their canopies (Bertness and Shumway 1993), offer protection from herbivores (McAuliffe 1984), or increase soil nutrients beneath their canopies (Callaway et al. 1991).

Recent research presuming multiple, interacting causal mechanisms for community structure has demonstrated that facilitation and interference may operate simultaneously and that the overall effect of one species on another may vary among different microhabitats as mechanisms shift in relative importance (Callaway et al. 1991; Bertness and Hacker 1994; Bertness and Yeh 1994; Chapin et al. 1994). Complex combinations of negative and positive interactions operating simultaneously suggest that current conceptual models of interplant interactions based on resource competition alone are limited in their potential for accurately depicting processes in natural plant communities. In an attempt to integrate biotic and abiotic factors into one model, researchers have hypothesized (Bertness and Callaway 1994) that the relative importance of interference and facilitation may vary inversely along gradients of abiotic stress; the importance of facilitation is predicted to increase, and the importance of interference is predicted to decrease along a gradient of increasing abiotic stress. Here we provide the first test of this hypothesis.

In 1993, we observed positive spatial associations between a rare endemic mustard, Lesquerella carinata var. languida (Brassicaceae), and bunchgrasses on the xeric, rocky slopes of the Garnet Range in western Montana; however, the association was evident at some sites and not at others. To expand our understanding of both the role of positive interactions in ameliorating abiotic stress in 
harsh environments and variation in the relative importance of interference and facilitation, we conducted field experiments that examined facilitation and interference between Lesquerella and bunchgrasses among sites and years varying in apparent abiotic stress.

\section{METHODS}

\section{Species and Site}

Lesquerella carinata var. languida Rollins (Garnet bladderpod) is a short-lived rosette- and taproot-forming perennial herb. It is endemic to western Montana, where it grows on easily disturbed, gravelly, calcareous soils on south- to westfacing slopes. Common associated species in this xeric habitat are bunchgrasses (Pseudoregneria spicata [Pursh] Löve [bluebunch wheatgrass], Koeleria cristata Pers. [prairie junegrass], and Festuca idahoensis Elmer [Idaho fescue]), Purshia tridentata (Pursh) D.C. (bitterbrush), and Pinus ponderosa Dougl. (ponderosa pine). The study populations are located at Rattler Gulch (elevation 1,640 m, $46^{\circ} 44^{\prime} \mathrm{N}, 113^{\circ} 16^{\prime} \mathrm{W}$ ) and Bear Gulch (elevation $1,311 \mathrm{~m}, 46^{\circ} 45^{\prime} \mathrm{N}, 113^{\circ} 21^{\prime} \mathrm{W}$ ). The Rattler Gulch site faces south, and the Bear Gulch site faces west. Vegetation at the Bear Gulch site is characterized by mesic species such as Galium boreale, Allium cernuum, and Pseudotsuga menziesii, while at Rattler Gulch vegetation characteristic of xeric habitats such as Opuntia fragilis, Juniperus scopulorum, and Pinus ponderosa is more common. Based on vegetation and aspect, we designated Rattler Gulch as a relatively "high-stress" site and Bear Gulch as a "lowstress" site.

\section{Spatial Pattern Analysis}

To quantify spatial associations between bunchgrasses and Lesquerella, we determined vegetative cover in May 1993 in 60 randomly selected $0.25-\mathrm{m}^{2}$ plots along a randomly positioned $50-\mathrm{m}$ transect at Rattler Gulch and 20 randomly selected plots at Bear Gulch. In each plot, we measured relative cover of open, bunchgrass, litter, and forb canopies to the nearest $5 \%$. For our spatial analysis, all bunchgrass species were combined. At each site, we randomly located a different 50-m transect in which all adult Lesquerella were identified within a $1-\mathrm{m}$ radius of randomly selected sampling points along the transect, and the associated cover for each Lesquerella was recorded. Cover type associations were measured for 286 Lesquerella at Rattler Gulch and 110 at Bear Gulch. A $\chi^{2}$ test of goodness of fit was used to analyze the distribution of Lesquerella.

To test whether bunchgrass-associated Lesquerella discriminated among bunchgrass species, relative bunchgrass cover was determined for 50 randomly selected bunchgrasses in yet a different 50-m transect at Rattler Gulch. A $\chi^{2}$ test was used to analyze the association of 51 randomly chosen Lesquerella with bunchgrasses as described above. A final $50-\mathrm{m}$ transect was selected for this analysis, and only one Lesquerella per bunchgrass was used. Because expected cell counts for Koeleria and Festuca are less than five, these two classes were pooled for calculating the $\chi^{2}$ statistic. 


\section{Facilitation Experiment}

We conducted manipulative field experiments at Rattler Gulch in 1993 as tests for interference and facilitation. Stress experienced by the plants that year was probably much less than normal, since it was cooler, wetter, and cloudier than usual. Data gathered at the U.S. Weather Bureau Station in Missoula, Montana ( $80 \mathrm{~km}$ west of study area; elevation $975 \mathrm{~m}$ ), indicate that July 1993 was the coolest on record since 1892 and the tenth wettest since 1896; mean June and July temperatures, precipitation, and cloud cover were $14.6^{\circ}$ and $15.2^{\circ} \mathrm{C}, 36.8$ and $51.3 \mathrm{~mm}$, and 21 and $16 \mathrm{~d}$, respectively (National Oceanic and Atmospheric Administration 1993). In contrast, 1994 was much warmer, drier, and less cloudy than 1993 (see below).

Lesquerella seeds were planted under bunchgrass canopies, in the open, "under" clipped bunchgrass canopies, and under artificial shade, which was provided by Hummert's $47 \%$ shade cloth. We planted 224 seeds into each of four randomly chosen $4 \times 7 \mathrm{~m}$ blocks. Each block consisted of $281-\mathrm{m}^{2}$ plots, and each plot contained two bunchgrass treatments, two open treatments, two clipped bunchgrass treatments, and two shade treatments. Lesquerella does not discriminate in its association with different bunchgrass species, so we chose mature bunchgrass clumps randomly without regard to species. All treatments were randomly located within each plot. Before planting, the seeds were scarified with sandpaper and stratified at $1^{\circ}-2^{\circ} \mathrm{C}$ in the dark for $1 \mathrm{mo}$. We planted seeds in mid-March 1993, censused seedlings weekly until May 8, and then monitored seedlings approximately every $10 \mathrm{~d}$ thereafter until September 19,1993 . At this time, the seedlings were removed and dried at $50^{\circ} \mathrm{C}$ until repeated weighings showed no change in mass.

Seedling survivorship was analyzed in two ways. First, a loglinear model was used that included block, treatment, and survivorship. However, because several of the expected cell counts were less than one, the $\chi^{2}$ approximation may not have been valid. Therefore, we also carried out the analysis as a two-way $\chi^{2}$ test of goodness of fit in which we ignored the block effect, which did not have a significant effect on survival according to the first analysis. Both of the analyses showed a significant effect of treatment on survival (see Results), and we report the results of the second analysis.

Root and shoot biomass values were log transformed to normality and analyzed in two ways because cells were missing in the ANOVA table. First, the incomplete block was dropped, and a mixed-model MANOVA (including the interaction term) was performed. Second, the incomplete block was kept, and a MANOVA without the interaction term was performed. Planned contrasts were used to compare the experimental treatments (canopy, clipped canopy, shade) with the control (open). Neither analysis was significant (see Results), so the first analysis is reported.

The facilitation experiment was performed again at Rattler Gulch in 1994, which was much drier, warmer, and less cloudy than 1993; mean June and July temperatures, precipitation, and cloud cover were $15.5^{\circ}$ and $21.2^{\circ} \mathrm{C}, 36.8$ and $23.9 \mathrm{~mm}$, and 11 and $3 \mathrm{~d}$, respectively (National Oceanic and Atmospheric Administration 1994). Because germination of our hand-planted Lesquerella seeds was very low 
TABLE 1

Distribution of LesQuerella CaRinata With Respect to Vegetation Cover TYPE AT Both STUdy SITES IN 1993

\begin{tabular}{|c|c|c|c|c|}
\hline \multirow[b]{2}{*}{ Study AreA } & \multirow[b]{2}{*}{ COVER TyPE } & \multirow{2}{*}{$\begin{array}{l}\text { Relative } \\
\text { Frequency }\end{array}$} & \multicolumn{2}{|c|}{$\begin{array}{c}\text { Number of AsSOciated } \\
\text { LESQUERELLA }\end{array}$} \\
\hline & & & Observed & Expected \\
\hline \multirow[t]{3}{*}{ Rattler Gulch* } & Open & .802 & 110 & 229 \\
\hline & Bunchgrass & .151 & 135 & 43 \\
\hline & Forb & .047 & 41 & 13 \\
\hline \multirow[t]{4}{*}{ Bear Gulch $\uparrow$} & Open & .055 & 19 & 6 \\
\hline & Bunchgrass & .166 & 13 & 18 \\
\hline & Litter & .744 & 74 & 82 \\
\hline & Forb & .036 & 4 & 4 \\
\hline
\end{tabular}

* For this site, $n=286, \chi^{2}=315.6$, df $=2$, and $P<.0001$.

$\dagger$ For this site, $n=110, \chi^{2}=29.97$, df $=3$, and $P<.001$.

in 1993, we used naturally occurring seedlings in 1994 to ensure adequate sample sizes. Sixty randomly located seedlings were assigned per treatment (bunchgrass canopy, open, clipped bunchgrass canopy, shade) on April 30; survival was measured on June 18, July 4, July 26, and August 20. On August 20, remaining seedlings were harvested for biomass measurement as described above. A twoway contingency table was constructed for $\chi^{2}$ analysis of the 1994 survivorship data, loglinear analysis was used to test for an effect of the year-by-treatment interaction on survivorship, and a protected MANOVA (Scheiner 1993) was used for analysis of the log-transformed root and shoot biomass data. We cannot test the biomass data for a significant year-by-treatment interaction because too few plants survived in the open and clipped treatments in 1994.

The same facilitation experiment was also performed at the more mesic Bear Gulch in 1994 to assess the relative importance of facilitation versus interference in what we considered to be a relatively low-abiotic-stress environment. The methods, measurement dates, and data analysis were the same as those described at Rattler Gulch in 1994, with the exception that 50 seedlings per treatment were used.

No physiological measures of stress were taken in either year; however, the significant differences in overall seedling survivorship between 1993 and 1994 ( $78 \%$ vs. $6 \%$; see Results) and between the mesic and xeric site (39\% vs. $8 \%$; see Results) support our evaluation of these years and sites with respect to abiotic stress.

\section{RESULTS}

\section{Spatial Pattern}

Adult Lesquerella showed significant positive associations with bunchgrasses at the high-stress site, Rattler Gulch. Although open, gravelly soil was the predominant cover type, occupying $80 \%$ of the area, $47 \%$ of Lesquerella occurred under the canopy of bunchgrasses, which composed only $15 \%$ of the vegetative cover (table 1). Lesquerella that occurred under bunchgrass canopies did not 


\section{TABLE 2}

\begin{tabular}{|c|c|c|c|}
\hline \multirow[b]{2}{*}{ COVER Type } & \multirow{2}{*}{$\begin{array}{l}\text { ReLATIVE } \\
\text { FrEQUENCY }\end{array}$} & \multicolumn{2}{|c|}{$\begin{array}{l}\text { NUMBER OF } \\
\text { ASSOCIATED } \\
\text { LESQUERELLA }\end{array}$} \\
\hline & & Observed & Expected \\
\hline Pseudoregneria spicata & .88 & 46 & 44.9 \\
\hline Koeleria cristata & .08 & 5 & 4.1 \\
\hline Festuca idahoensis & .02 & 0 & 2.0 \\
\hline
\end{tabular}

discriminate among bunchgrass species (table 2). At the low-stress site, Bear Gulch, a negative spatial association was observed with fewer adult Lesquerella positioned under bunchgrass canopies than expected, and more were found in the open and in the litter layer (table 1).

\section{Field Experiments}

In 1993, 76 of $896(8.5 \%)$ Lesquerella seeds germinated in all treatments combined, and there were no significant differences in germination between treatments. At Rattler Gulch, the effects of bunchgrasses on Lesquerella varied between years. Although there was a positive spatial association of Lesquerella and bunchgrasses at Rattler Gulch, we found no experimental evidence of facilitation in 1993. In this cool, wet year, significantly fewer experimental seedlings survived under bunchgrass canopies than in the open (fig. 1A), which demonstrates that interference was the predominant interaction between bunchgrasses and Lesquerella. No significant differences in root or shoot biomass were found between the open and bunchgrass treatments (fig. $2 A$ ).

Seedling survival and root biomass were substantially lower at Rattler Gulch during the hot, dry summer of 1994 than in 1993. Average survival of Lesquerella seedlings across all treatments was $78 \%$ in 1993 versus only $6 \%$ in 1994 (fig. $1 \mathrm{~A}$, $B ; \chi^{2}=154.3$, df $=1, P<.001$ ). Root biomass over all treatments was significantly lower in 1994 than in $1993(t=-3.013$, df $=78.2, P=.003)$. Of the original 60 seedlings in each treatment in 1994 , fewer than 10 survived per treatment, with one and none surviving in the open and under clipped bunchgrass, respectively (fig. 1B). Lesquerella survival was significantly higher under bunchgrass canopies and under artificial shade than in the open and under clipped canopies $\left(\chi^{2}=28.1\right.$, df $\left.=3, P<.001\right)$. Most important, the differences in seedling survivorship among treatments between 1993 and 1994 were significant (loglinear analysis, $\chi^{2}$ [year $\times$ treatment $\times$ survival] $=25.7$, df $=3, P<.001$ ). Shoot and root biomass did not differ between plants grown under bunchgrass canopies and plants grown under artificial shade; comparisons to plants grown in the open and under clipped bunchgrasses could not be made because too few individuals survived in these treatments (fig. $2 B$ ). Overall, comparisons between 

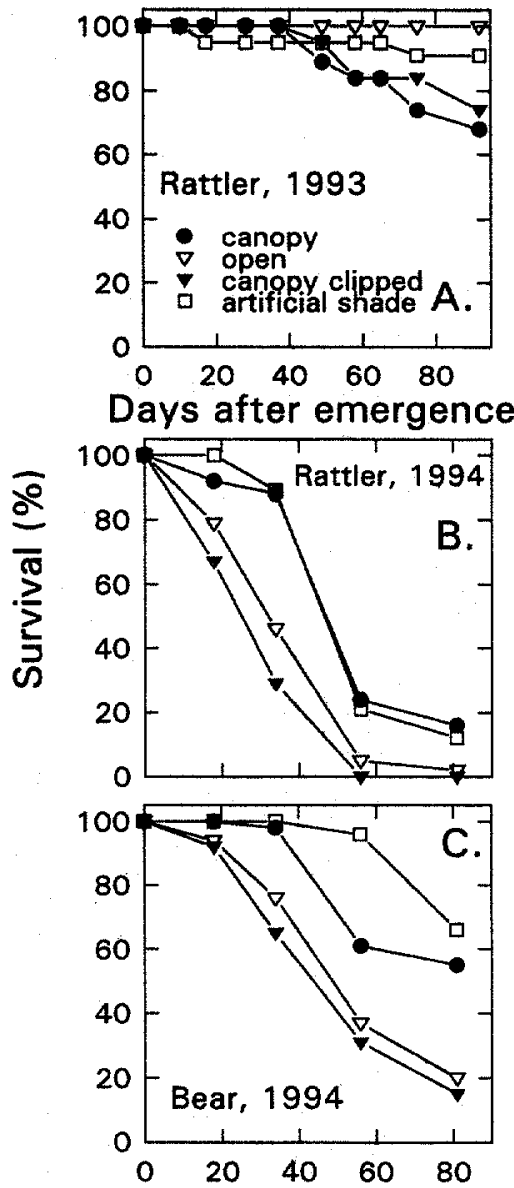

Days after clipping and shading

FIG, 1.-Survival of Lesquerella seedlings planted under bunchgrass canopies, in the open, under clipped bunchgrass canopies, and under artificial shade. $A$, Rattler Gulch, 1993; $\chi^{2}$ $($ for day 92$)=9.61$, df $=3, P=.022 . B$, Rattler Gulch, $1994 ; \chi^{2}$ (for day 81$)=14.4$, df $=3, P=.002$. $C$, Bear Gulch, 1994; $\chi^{2}$ (for day 81$)=40.25$, df $=3, P<.001$.

1993 and 1994 indicate that bunchgrasses facilitated Lesquerella seedlings via shade during the severe drought conditions at Rattler Gulch in 1994 but interfered with Lesquerella during the exceptionally cool, wet summer of 1993.

At Bear Gulch in 1994, Lesquerella survivorship was also significantly higher under bunchgrasses and artificial shade than in the open or under clipped canopies $\left(\chi^{2}=40.2, \mathrm{df}=3, P<.001\right)$. MANOVA revealed a significant treatment effect on root and shoot biomass at Bear Gulch (fig. $2 C ; \theta=.295, P=.036$ ). Planned contrasts revealed that root biomass of plants grown under the bunchgrass canopy or artificial shade was greater than that of plants grown in the open $\left(F_{\text {canopy-open }}\right.$ $\left.=5.199, \mathrm{df}=1, P=.029 ; F_{\text {shade-open }}=6.477, \mathrm{df}=1, P=.016\right)$. At the 


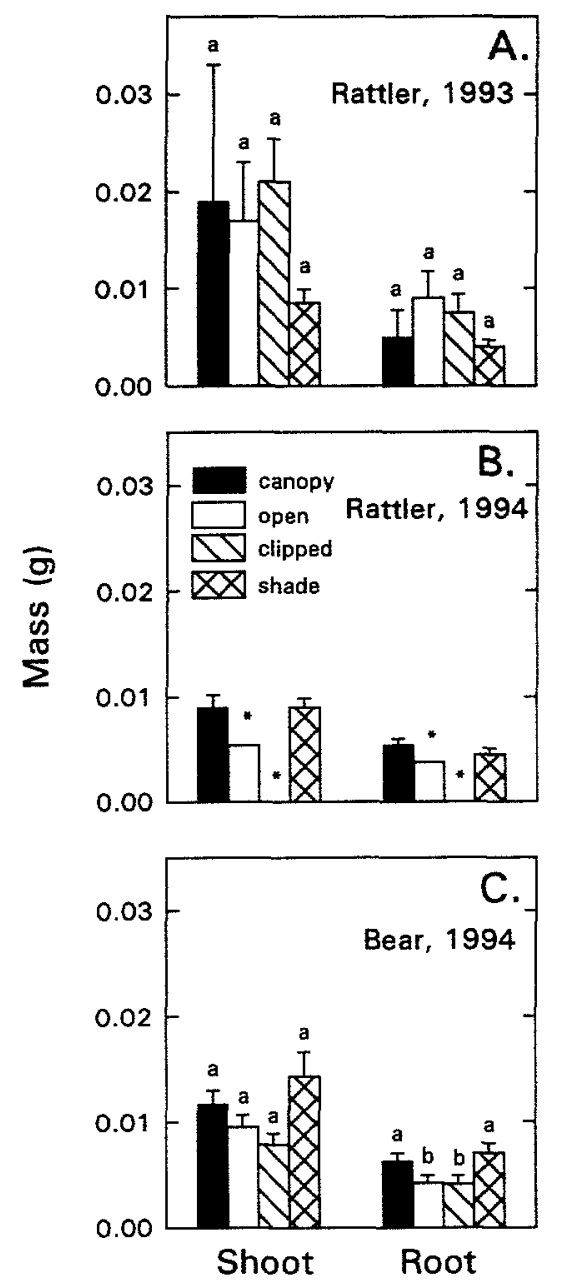

Fig. 2.-Shoot and root biomass of Lesquerella seedlings in four experimental treatments. Data are means and $1 \mathrm{SE}$. Means of experimental treatments with the same letter do not differ from the control at the $P<.05$ level with planned contrasts. $A$, Rattler Gulch, 1993; $\theta=.113, P=.375$. B, Rattler Gulch, 1994; Pillai trace $=0.252, F=2.18$, df $=2,13$, $P=.152$. No error bar is given for the open treatment because only one plant survived. No plants survived in the clipped treatment. $C$, Bear Gulch, $1994 ; \theta=.295, P=.036$.

high-stress site, final survival of Lesquerella was $2 \%$ in the open versus $16 \%$ under bunchgrass canopies (fig. $1 B$ ), while at the low-stress site, survival in the open was $20 \%$ compared to $55 \%$ under canopies (fig. $1 C$ ). Although the magnitude of the facilitative effect of bunchgrass did not differ significantly between sites, overall seedling survivorship was higher at the mesic Bear Gulch site than at Rattler Gulch (loglinear analysis, $\chi^{2}[$ site $\times$ survival] $=35.7$, $\mathrm{df}=1, P<.001$ ), which thus supports our evaluation of the sites as low- and high-stress environ- 
ments. Root and shoot biomass of Lesquerella did not differ between the two sites. These experimental results, which indicate the importance of bunchgrass facilitation of Lesquerella via a shading mechanism, correspond with positive spatial patterns at Rattler Gulch but contrast with the negative pattern of association between bunchgrasses and Lesquerella at Bear Gulch (table 1).

\section{DISCUSSION}

Annual variation in interspecific interactions is not unusual. Connell (1983), Schoener (1983), Fowler (1986), and Goldberg and Barton (1992) have documented annual variation in interspecific interference between plants. To our knowledge, however, our experiments provide the first evidence for temporal shifts in interference and facilitation between the same two species in a natural system. The correlation of these shifts to variation in abiotic stress provides insight into the relative roles these interactions play in establishing spatial patterns and relative abundances in plant communities. Differences between highand low-stress sites indicate that community structure in this system is strongly influenced both by the role bunchgrasses play in ameliorating abiotic stress experienced by Lesquerella and by interference between bunchgrasses and Lesquerella for resources such as light, water, and nutrients, but to varying degrees over time and space. Under mesic, less stressful physical conditions that permit rapid resource acquisition, bunchgrasses interfere with Lesquerella. However, under severe physical conditions, which may restrict the plants' ability to acquire these resources, amelioration of stress by neighboring bunchgrasses appears to be more likely to favor growth than interference is to restrict growth. Ultimately, community structure in this system may depend on the relative importance of these mechanisms on a background of varying abiotic stress.

Temporal variation in abiotic stress corresponded with more dramatic shifts in facilitation and interference than did spatial variation in stress. In 1994, bunchgrass facilitation was important at both the xeric site, Rattler Gulch, and the mesic site, Bear Gulch. The importance of facilitation suggested by experimental results at Bear Gulch contrasted with the negative association between bunchgrasses and Lesquerella shown in the spatial pattern analysis. The negative association suggests that interference between Lesquerella and bunchgrasses has played a more important historic role at Bear Gulch than facilitation. In comparison, bunchgrasses interfered with Lesquerella in the wet, cool year of 1993 at Rattler Gulch, contrasting with their positive spatial association. It appears that the long-term effects of facilitation have outweighed those of interference at the more xeric site.

We were unusually fortunate in that the summer of 1993 was one of the wettest and coolest in recent history in western Montana and that 1994 was much drier and hotter. Although we made no physiological measures of abiotic stress in 1993 or 1994, we feel that the extreme climatological differences between years are responsible for the strong shift in relative importance of facilitation and interference. Cloud cover was much higher in 1993 than in 1994; this measure was probably particularly important since it most likely reflects significantly less heat- 
ing of the soil surface by solar radiation during the low stress year. Furthermore, we observed no differences between years in other potentially confounding factors such as disturbance, cattle grazing, insect herbivory, or invasion by introduced plant species. Typically, temporal shifts in facilitation and interference are likely to be more subtle.

In addition to the climatically extreme summers of 1993 and 1994, the temporal variation in the importance of facilitation and interference may have been influenced by winter climate. Total precipitation in the winter of 1993-94 was much lower than in the winter of 1992-93 and may have accentuated early drought stress in the following xeric summer.

The mechanism of bunchgrass facilitation of Lesquerella probably involves a direct effect of shade, which may operate by decreasing leaf temperature, reducing transpiration losses, reducing evaporation of soil moisture, or preventing photoinhibition during drought. However, our experimental design prevents us from resolving the coarse mechanism of shade into one of these more specific mechanisms. Shade-driven facilitation has been demonstrated in deserts (Nobel 1984; Franco and Nobel 1989), oak woodlands (Callaway 1992), salt marshes (Bertness and Hacker 1994; Callaway 1994), and the congener Lesquerella fendleri, an herb of the Chihuahuan Desert in southwestern North America (Evans and Cabin 1995). Although herbivory often drives facilitative relationships (McAuliffe 1984, 1986), we did not observe differences in herbivory among treatments. The high concentration of glucosinolates and cyanides in many Brassicaceae often deters all but specialist herbivores (Chew 1988). Facilitation via nutrient accumulation has been demonstrated by some researchers (Barth and Klemmedson 1978; Callaway et al. 1991). Although some litter may accumulate around bunchgrasses and contribute to increased nutrient levels at these sites, our shade treatments were placed on open soil and were not in place long enough for nutrient accumulation to be a strong possibility. Nevertheless, Lesquerella seedlings survived better under artificial shade than in the open, which supports our assertion that facilitation occurred via a direct effect of shading.

Our experimental design had some irregularities; however, these do not significantly affect the interpretation of our results. Although Lesquerella seeds were manually planted for the experiments in 1993 and naturally germinated seeds were used in 1994, measures of performance were taken on the same life stage (seedling) each year. In addition, placement of Lesquerella seeds in 1993 was random, which thus further reduced chances for bias resulting from the use of experimentally placed seeds versus naturally occurring seedlings. Because sites and years were not replicated, we cannot draw conclusions for plant communities beyond these study sites. We merely conclude that shifts in the relative importance of facilitation and interference may be important in structuring some plant communities.

Grime (1977) and Welden and Slausen (1986) have suggested that competition becomes less important in stressful environments, but only recently has the importance of positive interactions in stressful environments been examined experimentally. We still know little about the relative importance of interference and facilitation in natural communities, and our conceptual models of community 
organization reflect this lack of understanding, as they largely emphasize competition for resources and the importance of interference in structuring plant communities. Here we provide the first evidence for shifts between interference and facilitation in years that differed in abiotic stress. Our work supports an earlier conceptual model of plant communities (Bertness and Callaway 1994) as complexly structured systems dependent on both interference and facilitation in a background of abiotic stress. Future studies of community organization that include multiple, interacting causes of community structure will lead to a clearer understanding of community structure and dynamics.

\section{ACKNOWLEDGMENTS}

We are grateful to L. Bacon, E. Caton, M. Sanger, C. Sarver, K. Menning, and S. Tardiff for field assistance and to D. Pilson for helpful critical advice throughout the experiment. This work was supported by a National Science Foundation Predoctoral Fellowship, a Conservation Biology Scholarship from The Nature Conservancy, and a University of Montana Faculty Development Grant.

\section{LITERATURE CITED}

Allee, W. C., A. E. Emerson, O. Park, and K. P. Schmidt. 1949. Principles of animal ecology. Saunders, Philadelphia.

Barth, R. C., and J. O. Klemmedson. 1978. Shrub-induced spatial patterns of dry matter, nitrogen, and organic carbon. Soil Science Society of America Journal 42:804-809.

Bertness, M. D. 1991. Interspecific interactions among high marsh perennials in a New England salt marsh. Ecology 72:125-137.

Bertness, M. D., and R. M. Callaway. 1994. Positive interactions in communities. Trends in Ecology \& Evolution 9:191-193.

Bertness, M. D., and S. D. Hacker. 1994. Physical stress and positive associations among marsh plants. American Naturalist 144:363-372.

Bertness, M. D., and S. W. Shumway. 1993. Competition and facilitation in marsh plants. American Naturalist 142:718-724.

Bertness, M. D., and S. M. Yeh. 1994. Cooperative and competitive interactions in the recruitment of marsh elders. Ecology 75:2416-2429.

Callaway, R. M. 1992. Effect of shrubs on recruitment of Quercus douglasii and Quercus lobata in California. Ecology 73:2118-2128.

1994. Facilitative and interfering effects of Arthrocnemum subterminale on winter annuals. Ecology 75:681-686. 1995. Positive interactions among plants. Botanical Review 61:306-349.

Callaway, R. M., N. M. Nadkarni, and B. E. Mahall. 1991. Facilitation and interference of Quercus douglasii on understory productivity in central California. Ecology 72:1484-1499.

Chapin, F. S., III, L. R. Walker, D. L. Fastie, and L. C. Sharman. 1994. Mechanisms of primary ciccession following deglaciation at Glacier Bay, Alaska. Ecological Monographs 64: 149-175.

Chew, F. S. 1988. Searching for defensive chemistry in the Cruciferae, or do glucosinolates always control interactions of Cruciferae with their potential herbivores or symbionts? No! Pages 81-111 in K. A. Spencer, ed. Chemical mediation of coevolution. Academic Press, New York.

Clements, F. E., J. Weaver, and H. Hansson. 1926. Plant competition: an analysis of the development of vegetation. Carnegie Institute, Washington, D.C. 
Connell, J. H. 1983. On the prevalence and relative importance of interspecific competition: evidence from field experiments. American Naturalist 122:661-696.

Evans, A. S., and R. J. Cabin. 1995. Can dormancy affect the evolution of post-germination traits? the case of Lesquerella fendleri. Ecology 76:344-356.

Fowler, N. L. 1986. The role of competition in plant communities in arid and semi-arid regions. Annual Review of Ecology and Systematics 17:89-110.

Franco, A. C., and P. S. Nobel. 1989. Effect of nurse plants on the microhabitat and growth of cacti. Journal of Ecology 77:870-886.

Goldberg, D. E., and A. M. Barton. 1992. Patterns and consequences of interspecific competition in natural communities: a review of field experiments with plants. American Naturalist 139: $771-801$

Grime, J. P. 1977. Evidence for the existence of three primary strategies in plants and its relevance to ecological and evolutionary theory. American Naturalist 111:1169-1194.

Kellman, M., and M. Kading. 1992. Facilitation of tree seedling establishment in a sand dune succession. Journal of Vegetation Science 3:679-688.

Lively, C. M., and P. T. Raimondi. 1987. Desiccation, predation, and mussel-barnacle interactions in the northern Gulf of California. Oecologia (Berlin) 74:304-309.

McAuliffe, J. R. 1984. Prey refugia and the distribution of two Sonoran Desert cacti. Oecologia (Berlin) 65:82-85.

1986. Herbivore-limited establishment of a Sonoran Desert tree: Cercidium microphyllum. Ecology 67:276-280.

1988. Markovian dynamics of simple and complex desert plant communities. American Naturalist 131:459-490.

National Oceanic and Atmospheric Administration. 1993. Local climatological data-annual summary with comparative data for Missoula, Montana. National Oceanic and Atmospheric Administration, U.S. Department of Commerce, Washington, D.C.

- 1994. Local climatological data-annual summary with comparative data for Missoula, Montana. National Oceanic and Atmospheric Administration, U.S. Department of Commerce, Washington, D.C.

Nobel, P. S. 1984. Extreme temperatures and thermal tolerances for seedlings of desert succulents. Oecologia (Berlin) 62:310-317.

Scheiner, S. M. 1993. MANOVA: multiple response variables and multispecies interactions. Pages 94-112 in S. M. Scheiner and J. Gurevich, eds. Design and analysis of ecological experiments. Chapman \& Hall, New York.

Schoener, T. W. 1983. Field experiments on interspecific competition. American Naturalist 122: 240-285.

Welden, C. W., and W. L. Slauson. 1986. The intensity of competition versus its importance: an overlooked distinction and some implications. Quarterly Review of Biology 61:23-44.

Witman, J. 1985. Refuges, biological disturbance, and rocky subtidal community structure in New England. Ecological Monographs 55:421-445.

John T. GreenLeE*

Ragan M. Callaway $\dagger$

\section{Division of Biological Sciences University OF MONTANA \\ Missoula, Montana 598I2}

Submitted May 17, 1995; Revised September 18, 1995; Accepted October 22, 1995

* Present address: United States Department of Agriculture, Lolo National Forest, Building 24, Fort Missoula, Missoula, Montana 59801.

$\dagger$ To whom correspondence should be addressed; E-mail: bi_rmc@lewis.umt.edu. 